\title{
Examination of Consumer Motivation and Expectation in the Case of Addiction Prevention Services
}

\author{
Tímea Beatrice Dóra ${ }^{1 *}$, Zsuzsanna Szalkai \\ 1 Department of Management and Business Economics, Faculty of Economic and Social Sciences, Budapest University of \\ Technology and Economics, H-1521 Budapest, P.O.B. 91, Hungary \\ * Corresponding author, e-mail: dora.timea@gtk.bme.hu
}

Received: 17 March 2020, Accepted: 14 February 2021, Published online: 18 November 2021

\begin{abstract}
The aim of this paper is to examine the consumer expectations and marketing communications related to the services of addiction prevention. The research questions of the study are the following: 1 . What are the front- and back-office components to addiction prevention services and what key attributes should the front office staff have? 2. What types of service gaps occur, and what are the most critical factors highlighted by these gaps? 3. How do consumers perceive addiction prevention campaigns and what are their expectations? In order to answer the research questions, secondary and primary research were conducted, where the Servuction; GAP; and AIDA models were applied. As primary research, in-depth interviews were conducted with healthcare professionals in Hungary. Based on expert opinion we assessed the possible GAPs related to the campaign, placing the greatest emphasis on the communication gap (GAP4). To examine the consumer response, we analysed the attitude and opinion of consumers with an online questionnaire survey in connection with the communication GAP of the service, following the structure of the AIDA model. This paper presents the factors affecting the environment, implementation and the consumers of addiction prevention services. Our results highlight the importance of positive messages, family therapy and continuous training of patients; moreover, they show that friends and general practitioners have more influence on the behaviour of people than celebrities and social trends. The results presented in our study can help healthcare managers or marketers to develop their communication programmes/campaigns.
\end{abstract}

Keywords

service marketing, consumer response, prevention, communication, health care marketing

\section{Introduction}

Today's healthcare system is able to prolong life expectancy and prevent diseases simultaneously, improving the standard of living of most citizens. Still, there are multiple areas of high priority in the health care system where, if they were to be successfully addressed, a large amount of serious and chronic conditions could be prevented. Addictions are shown to be a major problem, and most of them can be identified as the origin of certain "lifestyle" diseases (diseases of civilisation) (Bitar, 2018) that contribute to numerous deaths in Hungary every year. The frequency of lifestyle diseases resulting from such addictions is also high both at European and global levels (Mackenbach et al., 2015). In most cases alcoholism, smoking and the use of illicit drugs are reported as disease triggers.

In Hungary every year 32,645 people die due to ischemic heart disease (including myocardial infarction) and heart failure, 32,844 from malignant tumours,
11,384 from cerebrovascular disease (mainly STROKE) and 6,110 citizens from pulmonological conditions, such as COPD, pneumonia, or asthma (HCSO, 2017). Behind many of these mortalities we can identify underlying addictions, such as smoking and alcoholism, but illicit drug abuse is also a non-negligible factor. According to the latest data from WHO, the prevalence of daily smoking in 2017 was $25.8 \%$ in Hungary. After Greece, this is the second highest rate in the European Union and 5th highest in the world (OECD, 2019).

Alcohol consumption is also a very high risk factor, due to the relatively high number of "heavy drinkers" in the country $(5.4 \%$ of the citizens, who admittedly drink every day). $65 \%$ of the remaining population consumes alcoholic drinks occasionally or rarely (HCSO, 2015). An average Hungarian consumes 10.8 litres of pure alcohol a year, a figure that is surprisingly not outstanding by European 
cultural standards (in this respect, the country is positioned within the middle third of EU countries) (OECD, 2019).

Nevertheless, Hungary's 75 per 100,000 alcohol-attributable standardised death rate (liver disease, tumours, accidents, suicides due to alcohol-attributable mental disease) is extremely high, and it can be compared only to Romania and ex-Soviet Baltic states in the EU (WHO, 2013). Illicit drug abuse in Hungary is below average in comparison with other EU countries, except for designer drugs and amphetamine-derivatives (EMCDDA, 2018). The latest study in the topic revealed that $9.9 \%$ of citizens aged between 18 and 64 years consumed an illicit drug at least once during their lifetime, but among early adults (18-34 years) that statement is true for $17.7 \%$ (Paksi et al., 2018). Here, it needs to be acknowledged that the statistics are mostly based on self-declaration and their interpretation is stratified by the fact that citizens with a bad socio-economic status are especially affected. Epidemiological data indicates that among adolescents and young adults the popularity of these addictions is particularly high, a fact that justifies an increasing need for the extension of addiction-prevention services within our healthcare system.

It is generally accepted that establishing health-awareness is essential even before the occurrence of lifestyle diseases and other health-threatening conditions. Thus, it is important to educate people about the real purpose of healthcare systems, something that is not only about the treatment of already manifested conditions (Hahn and Truman, 2015). Activities, like teaching citizens about health-awareness and actively assisting them to lead a healthy lifestyle are called prevention. Prevention, in accordance with its service objectives, attempts to prevent or delay the development of the above-mentioned addictions, and can be identified at the primary level of healthcare. In terms of their purpose, preventive activities focus primarily on the prevention of diseases, but the interpretation of the definition is considered more complex from the point of everyday health practice. Taking into consideration the possibility of genetic inheritance of several diseases (Goldman et al., 2005), and the fact that ageing societies are now commonplace, prevention has a more explicit aspiration: "we call prevention the entirety of activities that decrease the incidence of numerous diseases, while adjourning their appearance in other illnesses so as to reduce the ensuing difficulties" (Ádány, 2012:p.25). According to Caplan (1964) in the field of prevention we can differentiate between three levels: primary-, secondary- and tertiary prevention. The general focus of primary prevention is health protection, disease- and harm prevention. The purpose of these activities is to increase attention and strengthen education about lifestyle, especially towards people who are healthy. Secondary prevention is based on a variety of screenings to discover the health parameters of risk and to identify chronic diseases in their preclinical stages. Tertiary prevention includes activities focused on the recovery and treatment of conditions and the prevention of complications. Processes such as therapy or rehabilitation are recognised recovery treatments, and viewed as part of tertiary prevention (Simeonsson, 1991).

When it comes to addiction prevention, it is of the utmost importance to emphasise prevention at every specified level, providing a high-quality preventive care service (Kelley et al., 2004) that can be greatly supported by a marketing approach. The specificity of prevention activities at each level should be clarified and should be considered when designing services. The key factor is to understand and communicate the value generated or created by the service (Zainuddin et al., 2011). The unique features of each service component, individually designed, can help raise awareness and create the right impression for citizens. The positive impact of well-managed social networking is understood from a corporate point of view (Tokarčiková, 2011), but it also plays a pivotal role from the government's side. Based on the benefits of social networking, communication with citizens should not only include information about illnesses, but also should convince the people about the importance of prevention and about turning towards a healthy lifestyle (Regidor et al., 2007). In this context, the development of the applied marketing communication mixes (Aras et al., 2018) is of paramount importance; consequently, this is considered to give people their first impression about the significance of prevention.

In this paper, health care prevention as a service is first introduced, then the service components and possible gaps are analysed, based on the Servuction and GAP models of service marketing. In order to examine further the communication of prevention services, consumer expectations, and motivations toward addiction prevention services, three research questions were formulated. In the Research Methodology section, the two studies - Study 1 and Study 2 - are introduced. We then present results for these two studies. In the first study we intend to formulate interview-based service specifications and composition. In our second study we summarise the results of a questionnaire survey based on the "Dry November" online prevention programme to assess consumer expectations and 
communication response. Finally, conclusions and managerial implications are drawn from our findings. The paper ends with further research suggestions.

\section{Prevention as a service}

In our approach we interpret addiction prevention by focusing on the main components of the applied services and as feedback we investigate the specifics of consumer satisfaction as well. As a starting point for our investigation, we begin by defining the concept of a service. By definition, service is an act or performance which is provided by one party to the other and which is not material in nature and does not give rise to ownership of anything. Its production is either related to a physical product or not (Kotler et al., 2002). By narrowing down the definition of service to the area of healthcare it is defined that "the object of service is the human itself, in which case we mean maintaining or restoring the functioning of the body as an organisation (health service) and, on the other hand, shaping and enriching the emotional components of the body (psychological counselling, leisure activities)" (Simon, 2010:p.73). In connection with this, healthcare or healthcare-oriented service providers can also be classified according to type of activity: communal services, catering services, travel, transportation, finance and insurance, legal and economic services, body care, detoxification, entertainment, education, health and welfare services, education and research, and official and institutional services as well (Veres, 2005). However, in terms of focus, each industry has many different service characteristics (Sasser, 1976). Grönroos (2007) states that there are three common characteristics that apply to all services: the service is a physically intangible activity, which needs both production elements and consumption elements. In the case of addictions, prevention first aims to prevent the emergence of dependency or mitigate it if it is already present (Price and Emshoff, 1997). At the first, primary level of prevention, healthcare activity tries to avert a person, who has never used the substance before, from the possibility of developing an addiction. Secondary prevention aims to decrease further harm in a patient, who has considerable history of abuse or dependency, while tertiary prevention deals with patients who are already addicts. Its main goal is to reinstate and rehabilitate these individuals (by means of programmes, psychotherapy, pharmaceutical treatments) into society and aims always to monitor their condition.

Primary prevention of addiction mostly operates at the level of national programmes and campaigns targeting elementary and high schools at a municipal or district level (Bíró et al., 2018). However, national programmes usually act as parts of extensive, multi-area programmes, targeting groups comprising a limited number of individuals, are carried out by mental hygiene professionals, general practitioners and health visitors, and their prevention campaigns are more focused on a specific addiction (alcoholism, drug abuse, etc.). General practitioners, health visitors, and high school psychologists contribute to the field of secondary prevention, with the aim being to focus attention towards temperance and harm-avoidance. In the case of tertiary prevention, the presence of professional clinical psychologists and psychiatrists is required to restore the mental health of patients suffering from addictions via psychotherapy or medication (Howard et al., 1988).

\section{Service components and possible GAPs}

In relation to the content of prevention services we now scrutinise the Servuction system model, broadly used in marketing research, which enables us to give a thorough analysis of services connected to addiction prevention. The Servuction system was implemented to highlight the interactions among consumers, to present the visible and non-visible constituents of the provider side and to define customer value (Kenesei and Kolos, 2014). Frequently referred to as the "Model of the Service Firm's Customer Relationships", its main focus is the optimisation of resource configurations for interactive marketing strategies, or for the planning of future actions (Grönroos, 2007). In our case, we interpret customer value in the context of social well-being, interpreted as a public value (Alford and Yates, 2014) for the citizens of Hungary. The model breaks down the elements of experience-marketing, based on their visible- or invisible nature in the eyes of the consumers. Visible service components (the so-called "front office") on the provider side include the physical devices involved in the service, the behaviour of the staff, and factors that can be perceived directly by our sensory organs (Eiglier and Langeard, 1976). Every front office component is essential, so at the primary and secondary level, we take into consideration marketing and information materials, and the available fleet of instruments to measure health damage from addiction. However, for tertiary prevention, environmental factors for rehabilitation are crucial in respect of where patients' sessions and therapies take place. As with many other articles about service quality, it is the appearance and behaviour of front office staff that mostly shapes customer perceptions, and this is identified as a key component of 
customer value (Ramachandran and Chidambaram, 2012), something that should be always taken into consideration. Invisible components (the so-called "back office") can be summarised as being the establishment and organisation behind the service itself; this includes the strategy, resources and internal operational efficiency of companies (Eiglier and Langeard, 1976). In the case of these components (which are elements of internal marketing) of the service, it is important to acknowledge that these are elements that enable service implementation and provide the content of the customer value, including all items that help to create the front office resources (Joseph, 1996). The model focusing on co-creation of customer value (Jaakkola et al., 2015) also considers the consumers as a resource of interaction, taking into consideration that they interact with each other, thereby forming their opinion of the service, something which also affects their preferences (Grönroos, 2007).

In the context of service production, we have to mention the GAP model used in the field of service marketing, which plays a key role in the aforementioned co-creation process for the treatment of addictions. According to the GAP model, quality problems can arise at several points in the service process from production to customer perception: these are the so-called "gaps". These gaps can be detected when a difference appears between consumer experience and consumer expectations (Zeithaml et al., 1990).

The model identifies 5 basic gaps. GAP1 marks the difference between consumer expectations and what the service provider thinks consumers would expect from the service. GAP2 is the difference between service development standards and interpreted consumer expectations. For GAP3, we can identify a gap between the defined standards and the service which is performed to the consumers. GAP4 gives the difference between the provision of the service and the communicated service, i.e. the difference between the advertised/promised and the actual service (Zeithaml et al., 2006). Finally, GAP5 relates to the difference between the received services and the expected service from the view of the consumers (Parasuraman et al., 1985). If all the gaps are "closed", that means the service provider fully produces the service that the consumer expects, thus makes the consumer satisfied. If there is a gap described (i.e. difference), that points to a quality problem that the service provider needs to correct or modify. This is particularly important in the case of health services, which affect a person's basic physical and mental well-being.

Regarding healthcare, examining communication is a key factor because it has the most impact on the consumers against the possible negative thoughts which can come from fear or the lack of information (Vermeir et al., 2015). In the case of prevention, this means an exceptionally large amount of information to be conveyed.

It is also established, that the information communicated does not always reach its target $100 \%$, due to various barriers, such as limited access and disparate levels of consumer-knowledge and perception (Süle, 2012). The extent and features of communication-comprehension can be examined using micromodels of communication, also known as consumer response models. These models provide the investigation of the reactions to marketing-communication that either reject or justify the impression created by the service (Kotler and Keller, 2012). Marketing-communication models assume that consumer evaluation has multiple segments: cognitive, emotional and behavioural (Simon, 2010). One of the most recognized of them is the AIDA model, elaborated by St. Elmo Lewis in 1898 to study the effects of marketing (Rehman et al., 2014). Although the model was revised many times since its inception it still stands its ground despite the appearance of myriad new technologies and transitions in economic and business environment (Michaelson and Stacks, 2011). The name of the model represents an acronym: Awareness, Interest, Desire, and Action (AIDA). The Awareness (cognitive segment) is the phase of raising awareness, the onset of consumer reaction, aimed to present the advantage of the service in an authentic, objective way. The aim of the Interest phase (emotional segment) is the generate genuine interest in the consumer and to influence it to gather further information about the product. The Interest phase is followed by the Desire phase (emotional segment), when optimally the consumer evolves an inner motivation to possess the product or to use the service. The Action phase (behavioural segment) already refers to the post-desire period, when the consumer takes action and buys the product or pays for the service. In this phase the consumer needs to be aided to carry out this act as smoothly and satisfactorily as possible (Hadiyati, 2016). Based on the AIDA model, evaluation of consumer opinion can reveal the extent of their commitment to make use of the marketed service.

\section{Research questions}

Supported by the information described above, the importance of the service components and the need to find the potential GAPs, including the need for a great deal of attention to communication, become highlighted. Taking 
these factors into account, we aim to answer the following research questions:

1. RQ1. What are the front- and back-office components to addiction prevention services and what key attributes should the front office staff have?

- To answer these questions, we made primary research among service providers. In the following parts of the paper we will refer to this research as Study 1. According to the possible gaps, customer value and the ramifications of the micromodel mentioned previously, we aimed to examine the opinion of the consumers.

2. RQ2. What type of service gaps can be identified, and what are the most critical factors of the service highlighted by these gaps?

3. RQ3. How do consumers perceive the campaigns and what are their expectations?

- To answer RQ2 and RQ3 a case study was conducted on a special program preventing alcoholism ("Száraz November" in English: Dry November). In the following parts of the paper, we will refer to this research as Study 2.

\section{Research methodology}

In this study, online and offline sources were used along with health databases as sources for the secondary research. Epidemiological data was collected essentially from WHO, HCSO (Hungarian Central Statistical Office$\mathrm{KSH}$ ) and OECD public databases. Our presented marketing models were driven from the field of service marketing and marketing communication along with the health care marketing perspective of the examined area. We meticulously described prevention levels with a concise literature review from medical disciplines concerning addictions and the relevant conditions.

The main findings of our research, where we focused on the content of a service in the context of building customer value were derived mainly from qualitative research. To determine the features of consumer satisfaction and response, we outlined one prevention programme, named "Dry November", which aimed to raise awareness against alcoholism. Apart from gaining insight from the opinion of our interviewee, we also asked participants of the programme through a questionnaire survey, where we received 81 valuable completed forms covering a variety of questions, including open questions and Likert-scale evaluation of personal viewpoints about alcohol consumption.

\subsection{Study 1}

Following the framework of our research, four in-depth interviews (Stokes and Bergin, 2006) and one e-mail interview were conducted with different healthcare professionals involved as service providers at all three levels of addiction prevention. Details about the interviewees are shown in Table 1. All interviewees have at least 7-10 years of experience and have participated in programme organisation related to prevention. Interview questions were aligned to a predetermined guideline based on our focus points, derived from the literature review and the examined models. All the interviews were conducted between November 2018 and February 2019. Discussions were audio-taped and noted down as sketch notes and analysed in terms of their content (except for the e-mail interview, whose answers were already in digital form). Programme leaflets, online materials and statistics also provided us a closer reach to the investigated area.

\subsection{Study 2}

Our sociologist informant is a key actor in our research, being the founder of the Dry November campaign upon which our case study is built. The results of the interview with him were analysed based on the GAP model and (here, paying special attention to the field of communication) the AIDA model, in order to reveal the service provider's opinion about the perception of each level of the model besides the specifics of the service content and possible GAPs regarding satisfaction.

The quantitative part of our research (Study 2, questionnaire survey) examined the opinion of consumers (partici-

Table 1 Specifics of the interviewees of Study 1

\begin{tabular}{|c|c|c|c|}
\hline Profession & Prevention level(s) & Institution (programme) & Interview type \\
\hline Health visitor & Primary & Fejér County Government: Department of Health Promotion (Health Days) & in depth interview \\
\hline General practitioner & Secondary & Szentmártonkáta, I. GP district (participation in rehabilitation programme) & e-mail interview \\
\hline Psychologist & Primary & National Korányi Institute of TB and Pulmonology (Quitting line programme) & in depth interview \\
\hline Psychiatrist & Secondary & Awakening Foundation (participation in rehabilitation programme) & in depth interview \\
\hline Sociologist & Tertiary & Blue Point Drug Ambulance (Dry November) & in depth interview \\
\hline
\end{tabular}


pants of the program) about the campaign appropriately suited to the levels of the AIDA model. The questionnaire ran online from the beginning of April 2019 until the end of May 2019, and once again during the campaign period November 2019 - January 2019, distributed specifically within the campaign's community group on a social media platform. Thus, membership of the group was a prerequisite for participating the survey. In the first part of the questionnaire, we aimed to survey the viewpoint of consumers on the campaign through open-ended and close-ended questions. In the second part, we used a projective technique (Malhotra, 2009) to design preventive campaigns for their own addiction in order to evaluate the expectation of consumers of such a prevention campaign.

For the quantitative assessment of online questionnaires all statistical analyses were generated by the PASW Statistics 22.0 package (SPSS Inc., Chicago, IL, USA). Data pre-processing and cluster analysis was performed with $\mathrm{R}$ packages, including ggplot2 ( $\mathrm{R}$ package version 0.7.7) for plotting heat map. For data pre-processing, no scaling method was used. We compared the results of the survey with the results of the interview with the sociologist and highlighted similar and different opinions based on the model presented as our conclusions.

\section{Discussion of results}

In the discussion section, we first intend to present the results of Study 1 connected to the Servuction model. Next, we expand our discussion with the results of Study 2, where we evaluate the peculiarities of the campaign concerning the possible GAPs revealed by the interviews and the specifics of the AIDA model received as a result of the questionnaire as consumer opinion.

\subsection{Front and back office components of addiction prevention- results of Study 1}

Based on the information collected from our interviews, we highlighted the key factors and components of the services provided in the field of prevention, regarding the most common addictions: smoking, alcoholism and the use of illicit drugs. The main resources can be identified as visible and invisible components of customer value, separated for each prevention level regarding the two main categories of addiction prevention services (prevention and rehabilitation) and the two types of potential customers (healthy citizens and addicted ones). In the case of front office elements, the ones that concern the staff (contact personnel) were differentiated. Therefore, we can separate the services and occupations (e.g. service providers) at a given level of prevention and evaluate, what are the key factors for these service providers.

On the primary and secondary level of addiction prevention we identified campaigns against smoking, alcoholism, and illicit drug use, by providing basic information (including possible diseases) and healthy lifestyle advices to the citizens, usually participating in rural or urban, prevention-based events of communities (so-called "health or community-days"). Here, we can also mention the lectures with educational purpose for children, smoking-, drug- and alcohol-prevention sessions in elementary or high schools. The programmes at this level usually employ health visitors, dietetics, and general practitioners. These events usually try to offer some types of screenings (measurement of blood pressure, blood sugar, vision test etc.) and directly relate to some form of advisement. The campaigns and/or programmes usually orientate people towards participating in different screenings locally, where the event takes place, or else direct them to their general practitioners for a further check-up. In case of primary prevention, it is critical to have well-planned flyers and promotion material in an appropriate amount and design. This also requires a logistical and storage network on the part of the providers. The health visitor mentioned that "the ordering, purchasing and on-site distribution of promotional materials has a well-planned management". The coordination of those working in the back office and the planning of primary prevention is an important point. At the planning stage at the primary level, the times of the events (which are usually attached to world health days as defined by the WHO) are determined. At the same time, they allocate available staff, configure delivery and release data, and also negotiate over media appearances and the communication strategy.

At the secondary level, the most important back office resources are the logistical resources (for screening equipment transport) and the analysing equipment to evaluate screening results. According to the general practitioner, the "climate conceived before each screening (such as waiting room furniture or light, temperature conditions) is also critical, because it affects the behaviour, beliefs and expectations of the patient". The visible components (Eiglier and Langeard, 1976) of these services (primary and secondary addiction prevention) also demand the right attitude and presence from providers (health care professionals), because these aspects strongly affect the demeanour of the patient (e.g. their attention, cooperation, or authentic behaviour with a constructive attitude). According to all 
interviewees, service behaviour in primary and secondary prevention has the greatest strength in communication. "If properly handled by a professional, this can create longterm trust and commitment through a healthy lifestyle". Both health visitors and general practitioners record risk factors that can be traced back, as patient history, in cases of treatment or health impairment (back office).

Regarding the third level of prevention, two programmes were examined. One that tries to help smokers to quit smoking, called the "Quitting line" programme, described as a "quick line" service. After applying to the programme, participants are invited to telephone therapy and chats to support and reinforce self-monitoring following the decision to quit. Its principle is to help the consumer make a decision that is strong enough to change their lifestyle. According to the psychologist "this is also a challenge for service providers, as they need to send a motivational message to consumers who do not know their own preferences". The programme conducts regular monitoring calls to document patient success. In connection with Blue Point Drug Ambulance (Marián et al., 2004) the Awakening Foundation (Bodrogi, 2011) also seeks to encourage the healing of distinct addictions through services that include individual-, family- and group therapy, along with psychiatric and psychological support. Sessions and therapies are held frequently, as the psychiatrist considers their most essential mission is "to shape patients' beliefs as soon as possible to achieve the greatest possible change". The behaviour and competencies of the providers have a strong psychological impact on the healing process and the self-confidence of the patients, right alongside the front office environment. According to the psychiatrist, a case can be traced back if enough data is available, that highlights the importance of the back office in cataloguing relevant information and keeping patient-history records. The main goal of these prevention services is to bring about a non-addictive physical state, because "if an individual becomes addicted, it cannot ever be healed entirely", but management of the disease is possible. Regarding the target population, each interviewee singled out younger people as the generation most in search of a sensational (sensory) adventure (from the age of 12).

The most prominent outcomes of the interviews are the service improvement suggestions. Professionals suggest, that in their experience, disincentive fear campaigns and adverts are not effective enough, instead they just create worthless fear of otherwise harmless circumstances. Preferably, they recommend that campaigns should address positive messages, such as success stories, on all available platforms. They also emphasise that the most prominent person in treatment are usually family members, consequently one of the most effective treatment is family therapy. By their conclusion, it would be beneficial to involve influencers or famous, well-known people in campaigns to have a significant influence on the target generation. Correspondingly, the urgent need for a nationwide programme, addressing prevention of the most common addictions, has to be stated.

\subsection{The Dry November campaign- results of Study 2}

Based on the topic of addiction prevention, we chose the Dry November campaign as the subject of our case study, which calls for a month-long period of alcohol abstinence, as a form of social challenge, or undertaking each year. The programme has grown on today's most well-known social networking platform site, and it is now advertised in newspapers, radios and on TV as well.

The results presented in this section are based on our interview with the sociologist informant (who is also the organiser of this program) and based on a survey among the programme participants.

\subsubsection{Possible gaps}

In the interview with the main organiser and initiator of the programme, we primarily sought information about consumer satisfaction to determine the possible gaps detected in the experience provided by the programme, and what could be further investigated among consumers.

The existence of the first gap (GAP1) may be justified by the fact that the programme organiser believes that they do not have enough information to assess people's exact needs. To achieve this goal (something that a nationwide campaign cannot fully achieve) the creation of an individual service is warranted. Although the programme tries to include specific themes in the campaign, such as women's alcoholism or the risk of becoming and alcoholic at a young age, the personal need of every citizens cannot be fully addressed in the design of the programme.

The second gap (GAP 2) can be considered closed based on the information we received, as the programme organiser does not feel that there is a problem with the service design currently. In his opinion, one of the most important factors in planning is the professional support that he and the organising team are providing, as the members of the team are also connected to the Blue Point Drug Ambulance in connection with the treatment of addiction. 
We could not associate information from the interviews with the existence of the third (GAP3) and fifth gaps, but we nevertheless examined the existence of the fifth gap (GAP5) with quantitative research linked to our case study.

Interestingly, the fourth, communication gap (GAP4) proved to be the most engaging. The organiser agrees that proper communication is the most convincing tool for any prevention campaign. Although the feedback on social networking sites leads him to believe that the message they communicate is largely understood by consumers, there may be differences in the interpretation and communication about the actual purpose of the campaign. To examine this in more detail, we used the AIDA model, which can show us the components of consumer response and satisfaction, examining the impact and influence on consumers through communication.

As a result, based on the model, first we present the characteristics of each step in the model from the service provider's point of view (according to the sociologist informant):

- Attention: Although the program has begun to attract attention as a social networking campaign, many people now are catching up with it on the radio and get informed about the Dry November from other online sources.

- Interest: The attention generated arouses interest in understanding the main message of the programme. Information from the interview and the program's online platform points out, that its principal mission is: "to moderate alcohol consumption" (Dry November Facebook Group, 2021).

- Desire: Most people join the programme because of the flock spirit, but in this case the concept of self-challenge emerged as well as a factor that can increase self-esteem. Our informant also emphasised that the programme can be used as a justification against community compulsive drinking, and it provides a good point of reference if someone does not want to drink alcohol at a social event.

- Action: As an answer to the question, that which feature of the program would cause consumers to take actual consumer action (30 days to avoid drinking), the interviewee mentioned that the programme acts as a "trigger to practise moderation through being a member of a community" (Dávid, 2019), the possibility to access the platform quickly and online, and share experiences. The results of the interview also highlighted that the programme would address the problem of alcohol abuse by building on community power.

\subsubsection{Consumer motivation and expectations}

Our professional interviewees highlighted, that according to the communication in tertiary prevention, personal connections, and the support of acquaintances matters the most in overcoming an addiction.

To measure this influence we asked the respondents, how much certain actors influence their drinking habits, including personal contacts, indirect contacts or no contacts at all.

Based on the results from the interviews we established the following hypotheses:

- H1: The power of community and the flock spirit representative of the "Action" phase of the AIDA model are the strongest factors contributing to the participation in the program.

- H2: Close social contacts, like friends, colleagues and family are the strongest influencing actors in drinking behaviour.

- H3: Celebrities through ad campaigns can influence drinking habits significantly by forming social trends are promoting a responsible behaviour.

We processed our questionnaire after obtaining 81 valuable answers. The respondents were aged between 18 and 64 , the majority (48 people, $59 \%$ ) was aged between 35 and 54. 49 (60\%) women and 32 (40\%) men completed the survey. The majority of the respondents (49 people, $60 \%$ ) has a higher education degree (BSc, MSc, PhD). 48 participants (59\%) started drinking between the ages of 14 and 18 . Furthermore, over $27 \%$ of the respondents drink on a daily basis and $49 \%$ of them weekly.

Based on the results of the interview with the programme founder, we structured our questions, focusing on each step of the AIDA model and compared the extent of agreement (Likert-scale) with the statements related to the Desire and Action phases to elucidate the preferences of the respondents. Kolmogorov-Smirnov test determined that all variables follow normal distribution, so we calculated differences using paired, 2-tailed t-test to evaluate participant answers (measured by Likert-scale).

- Attention: To identify the most successful device of gaining consumer attention, opinion of the respondents clearly highlighted the online attractiveness of the programme, as most of the responses $(64.2 \%=54$ people) reported that they encountered the programme on a social media site (where the group is operating).

- Interest: In terms of building interest, it is clear that the majority of those completing the programme 
understand the message of the programme (76 people, $94 \%$ ), that "the programme calls attention to moderate alcohol consumption". 4 people (5\%) indicated that the aim of the programme was the "elimination of alcoholism", while one person (1\%) stated that the aim of the programme was to "prevent the formation of alcoholism".

- Desire: To find out, why the consumers wanted to participate in the programme, we asked a question about how much they agreed with our given statements about the desire of joining. Based on this, the statements "Makes me stronger, I will be more persistent if I do it" (3.88 1.42$)$, "To show example to my

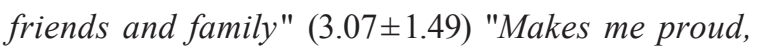
so I feel more valuable" $(3.45 \pm 1.44)$ were given the highest average scores on the Likert scale. The strength of these statements suggests that self-challenge is important for consumers, which can make them more balanced by increasing their self-esteem.

- Action: We enumerated the programme-specific values listed by the programme organiser as statements, and then asked the respondents to indicate which of them convinced them to participate in the programme. According to them, however answers, such as "Easier to cope, being in the community" (2.87 \pm 1.37$)$, "Being able to share their experiences or read others" (2.7 \pm 1.39$)$ and "Excuse not to drink at social events" $(2.82 \pm 1.55)$ received Likert scale scores in the upper half, they were still significantly lower than of statements of the Desire phase (pooled Desire: $3.47 \pm 1.28$ vs pooled Action: $2.8 \pm 1.11$, $\mathrm{p}<0.001$, Fig. 1). The three statements belonging to the Desire, or to the Action phase are not considered completely independent from each other, because of the significant conceptual overlap among them and their average mean values were pooled (Desire statements vs Action statements, Fig. 1).

We asked the respondents to evaluate to what extent friends, colleagues, general practitioners (GPs), and celebrities influence their drinking habits or their social drinking behaviour on a Likert scale questionnaire. One-way ANOVA analysis confirmed that means for each group vary significantly ( $\mathrm{p}<0.001$, Kruskal-Wallis statistic: 63.61$)$. We generated a heatmap to establish clusters of respondents influenced by different actors (friends, family, colleagues, general practitioner (GP) and trends/celebrities).

\section{Why have you entered the program?}

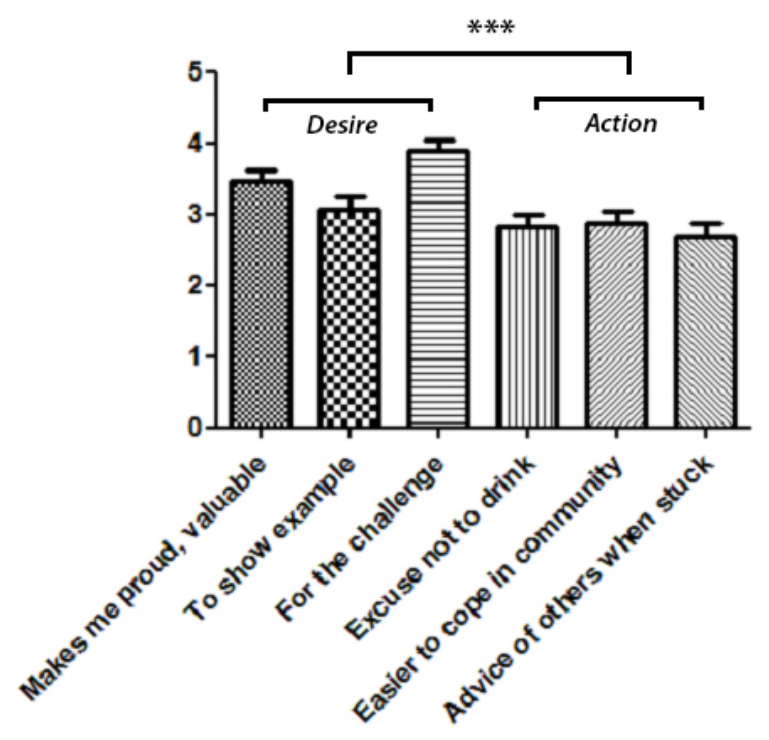

Fig. 1 Comparison of average scores given to each statement from the Desire and Action phase from 0-5 according to the Likert scale. Sample size: $(n)=81$, error bars indicate SEM of each value.

Heatmap and consequent hierarchical clustering reveals two main subsets of respondents, where subset $\mathrm{A}$ is basically influenced by all actors similarly, except for trends/celebrities. Cluster B is not that uniform and represent different subsets of respondents: those who trust only the GP (Cluster B2) and those who are rather influenced by trends/celebrities (Cluster B1). In cluster A we can distinguish a smaller subset of respondents who are influenced mainly by their colleagues and friends instead of their family and GPs (Cluster A2) (Fig. 2).

Table 2 shows representative respondent populations and their association with notable clusters. Due to the unequal number of participants in different participant groups concerning age (18-34: $31 \%$ and 35-54: 59 \%) and educational level (high school diploma: $36 \%$ and university degree: $60 \%$ ), we demonstrated the representation of each societal groups by showing how much of each different cluster is made up of representatives of that group.

Regarding age, there is only a slight difference in the case of cluster A1 and B2, where about the same percentage of young $(21 \%)$ and middle aged (26\%) people belonged to cluster A1 representing respondents that are equally influenced by their friends, families and GPs, but not influenced by trends/celebrities.

Similarly, there is only a marginal difference in the case of cluster B2 between the two societal groups (7\% vs 9\%). 


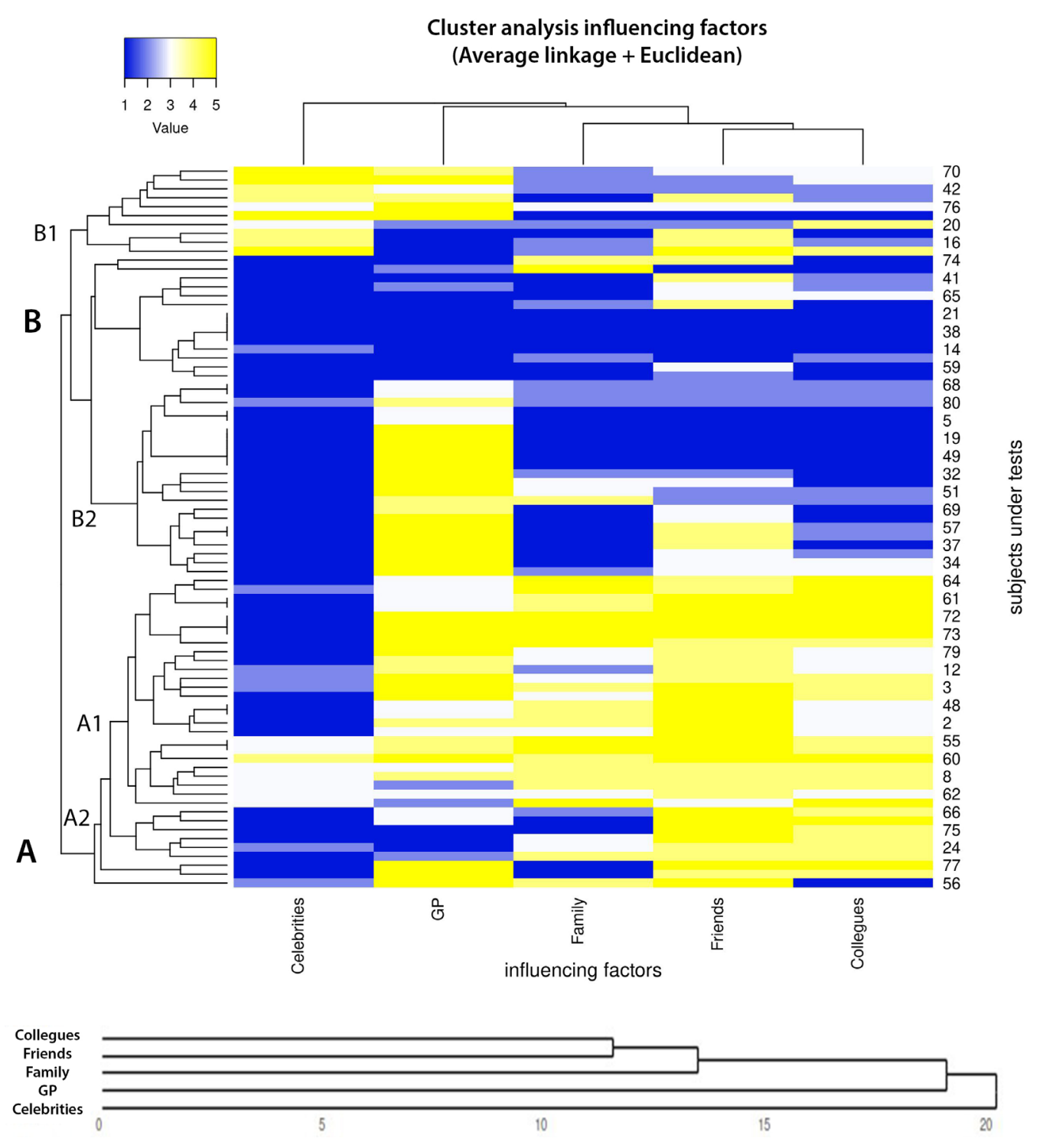

Fig. 2 Cluster analysis identified subsets of respondents according to the influential actors on their drinking behaviour. Each row represents a single respondent, and each column an influencing actor. At the bottom of the figure, a dendrogram depicts the hierarchical clustering of influencing actors. Scaling was determined based on Likert scale scores (1-5).

Table 2 Representation of respondent clusters among specific groups of participants (age and level of education). Significant differences are highlighted in the corresponding cells of the table.

\begin{tabular}{lcccc}
\hline Clusters & Aged 18-34 (young) & Aged 35-54 (middle-aged) & High school & University \\
\hline A1 (friends, family, colleagues, GP) & $21 \%$ & $26 \%$ & $29 \%$ & $28 \%$ \\
A2 (friends and colleagues) & $\mathbf{2 1 \%}$ & $\mathbf{1 \%}$ & $\mathbf{1 2 \%}$ & $\mathbf{4 \%}$ \\
B1 (mainly celebrities) & $11 \%$ & $17 \%$ & $18 \%$ & $20 \%$ \\
B2 (mainly GP) & $7 \%$ & $9 \%$ & $6 \%$ & $8 \%$ \\
\hline
\end{tabular}

However, there is a moderate difference in the case of cluster B1 (influenced mainly by trends/celebrities, $11 \%$ vs $17 \%$ ) and a significant difference in the case of cluster A2 (influenced only by friends and colleagues, $21 \%$ vs $1 \%$ ) between the two groups.
The latter result implies that a considerably higher number of young people (compared to middle-aged ones) is influenced only by their close contacts in their drinking behaviour. These respondents do not rely on more formal peers, like family and GPs. On the contrary, there is just negligible 
percentage of middle-aged people, who are not influenced by the GP and their families at all, which can be explained by their more established social status and family life.

We also compared respondents with a high school diploma to respondents with university degrees. The only cluster where a significant difference was detected between the two groups was again cluster A2, where $12 \%$ of participants with the maximum of a high school diploma (as compared to $4 \%$ with a university degree) belonged to this cluster, being influenced only by their friends and colleagues, regardless of age. Interestingly there were no major differences regarding the influence of GPs (18\% vs $20 \%$ ) and trends/celebrities ( $6 \%$ vs $8 \%$ ) between the two societal groups.

In conclusion, most influence-cluster represents miscellaneous respondent populations concerning age or degree and clustering does not really depend on these factors. However, there was a significant difference, detected in subcluster A2, where respondents are influenced only by their close and informal social contacts. Young people (aged 18-34) and people with maximum high school degree are considerably more represented in this respondent cluster.

A correlation matrix (Fig. 3 ) shows the correlation coefficients between respondent Likert scale scores according to influencer groups, where strong positive correlation is shown between the influence of friends and colleagues $(r=0.7)$ and moderate positive correlation is present between friends and family ( $\mathrm{r}=0.5)$ and colleagues and family $(\mathrm{r}=0.6)$.

There is no statistically significant correlation between celebrities and other influencing groups - this is also true in the case of GPs - that implies that these two groups of respondents form separate clusters influenced mainly by their peers and family. The latter findings are also supported by the results of the hierarchical cluster analysis shown in Fig. 2, where respondents influenced only by celebrities and GPs, respectively represent a cluster distinct from others.

In conclusion, we rejected our first hypothesis (H1), because statements related to the "Desire" phase of the AIDA model (challenge, pride and the feeling of self-confidence) were measured as significantly stronger incentives than factors related to the "Action" phase. We accepted our second hypothesis (H2), that most extensive influencing actors being close social contacts (friends, colleagues, family) and rejected our third hypothesis (H3) that celebrities could be strongly influential in guiding drinking behaviour. The latter actors were shown to influence only a smaller, distinct cluster of consumers according to our data (Fig. 2, Cluster B1).
The results lend support to the opinion of the health care professionals as close social contacts, like family, colleagues and friends are shown to have a strong influence, but they also make new perspectives possible in view of the unexpectedly strong influence of GPs and their advice. The results also contradicted one aspect of the professional standpoint, as celebrities making appearances on billboard or ads are not shown to be necessarily effective marketing strategies in addiction prevention.

In the last part of the questionnaire, regarding expectations "Clean head", "Sober", "Be present", "Restart" names were given by the respondents to their own prevention campaign after asking them to be the marketing managers for their own addiction-prevention campaign. The respondents would implement their campaign message and content. The marketing elements contributing to the success of the Dry November programme also occur in the design method and marketing messages interpreted by the respondents, therefore these communication factors are considered effective according to their experiences.

All responders declared that moderation and temperance should be the goal of their own imagined campaign, that aligns with the mission of the Dry November programme according to its organiser. The promotion of moderation and austerity achieved far more success than the message of total alcohol rejection and abstinence so far. According to our results each consumer should be targeted based on personal preferences and characteristics (39.5\%) and special attention should be paid to higher education and public schools as well as the target markets of such campaigns (39.5\%). Most of the respondents stated that the most effective platform is the internet (93.8 \%) and street billboards (44.4\%) were viewed as the second most effective communication platform. Regarding provided physical services, respondents labelled group sessions (75.3\%) and continuous screening and health monitoring (58 \%) as the most useful programmes in campaigns with the same purpose.

\section{Conclusions and managerial implications}

To summarise the opinions of the professionals while also considering the composition of services in the field of addiction prevention, it is clear that at the primary and secondary level of prevention the most important thing is to manage the content of channels transmitting information, and to perform screenings with up-to-date tools. At the primary level, the organisation of the planning, production, and delivery of brochures and flyers is a priority, as there is always a need for awareness-raising material that can convince a patient 


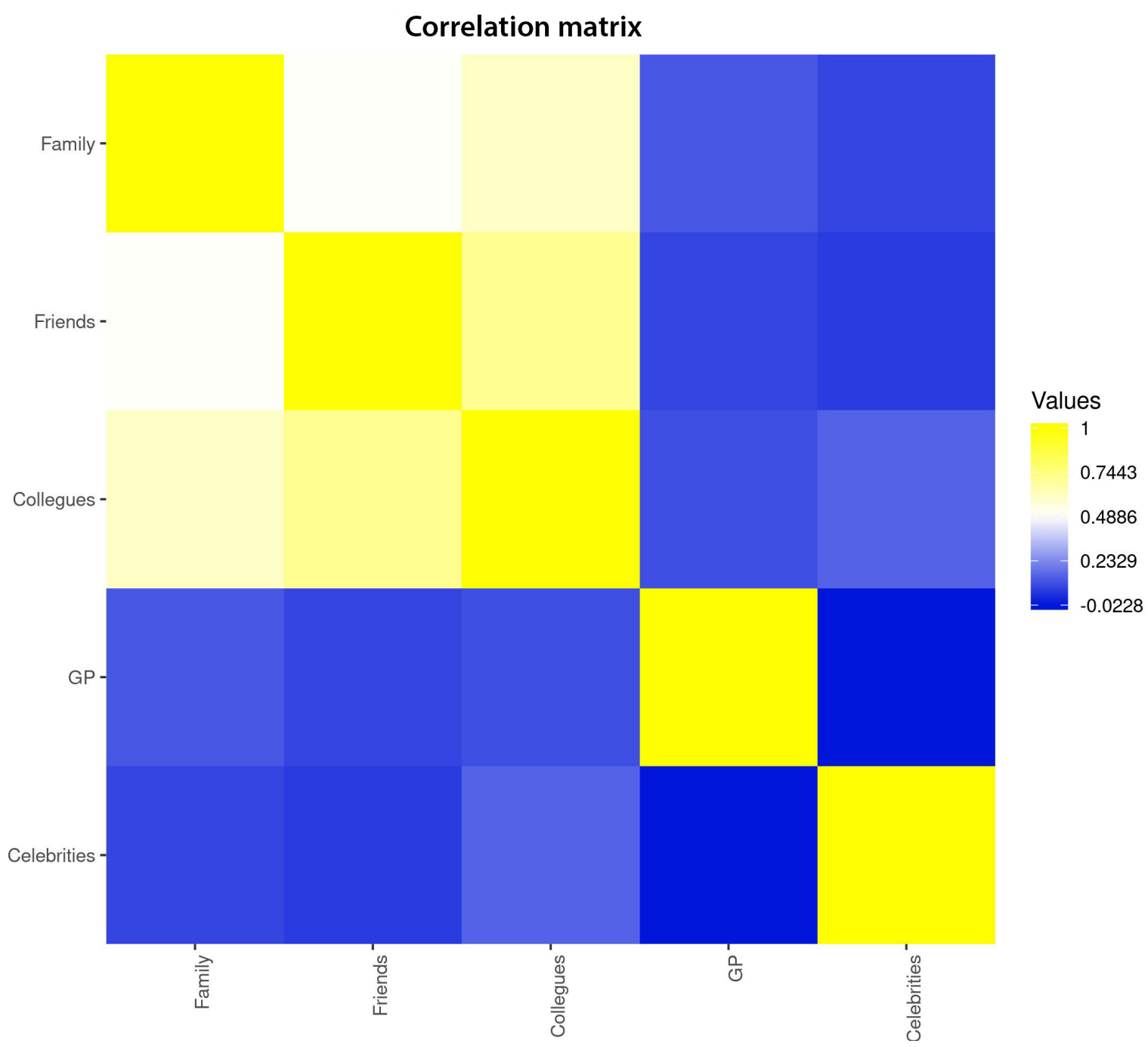

Fig. 3 Correlation matrix according to Spearman's rank correlation coefficients between Likers scale scores of different influencing actors

with potential or developed addiction that they may need further help. Providing a pleasant and safe physical environment, such as the appearance of the waiting room, doctor's office or the therapy room, influences the consumer, and this has a paramount importance at every level of prevention. Adequate management of these circumstances may affect the willingness of consumers to accept and process the information provided by these services. Of note, all our interviewees were fully aware that the behaviour of the professional staff was a crucial element in the attitude of the patient towards the healing process (admitting addiction, decision about healing). In the case of addictions, the way, how professional address and treat patients in a psychological sense (patience, listening to and focusing on the patient) is more important compared to cases of other conditions. Conveying positive messages is also crucial to achieve adequate motivation in patients. It is further emphasised that collecting patient-level data starting at the secondary prevention level can be extremely useful in tertiary prevention therapies, which can greatly assist professionals to plan therapy and accelerate the healing process. In order to manage the patient's cooperation skills in the field of addiction, it is essential to take the above into account. The skills required for this, such as comprehension, kindness, patience and the ability to cooperate, could be strengthened by training employees in this direction, and should also be mentioned as an important factor in the selection process of the staff from a management point of view.

Regarding the possible gaps, the first gap (GAP1) will always be open, due to the nature of the service of which the organising management is aware of. The results showed that a programme operating at a national level cannot create an utterly personalised service, although it is not its goal to do so. It cannot take into account the needs of each individual, 
in respect of which it would be expedient to examine another service (e.g. a specific treatment) in the field of addiction. It is certain from the results is that the communication gap (GAP4) is the most important for managers in similar services and campaigns, which should be paid the most attention to persuade as many consumers as possible.

With reference to the examination of consumer perception and expectations (GAP4 and 5), the comparison of the values indicated by the service provider with the values of the consumers is appropriate. In terms of the AIDA model these also clearly demonstrate the success of the online platform and its ability to convey its message clearly. Literature data suggests that whatever communication mix is used, besides personal selling, everything is feasible on the Internet (Bóta, 2009). However, consumers can be persuaded to join the programme if given the opportunity to be part of a community; interestingly, the phenomenon of experiencing self-challenge is an even stronger pulling power to join, rated significantly higher by the respondents than reference to unwanted occasions and the feeling of a flock spirit. According to the results of the research, a nationwide addiction prevention programme is needed (addressing several addictions), with sub-campaigns (such as Dry November campaign) not only to reduce consumption, but also to screen and reverse the pre-addiction state. Based on our results, it would be important to emphasise and manage the personal relationships of the addicts as well, especially friends and colleagues, whose influence is even stronger on younger people, who are the primary targets of the service. The results of our questionnaire show that the opinion and attitude of the GP is highly influential, regardless of the patient's age and education, clearly indicating that it should be given a pivotal role in prevention. Organisation of sensitisation training or involving GPs in advertising and indirect consumer communication would also be beneficial in the long term. Given the clear success of the online platform, it would be worth promoting this programme on the internet and to build a positive-message campaign in the future that could turn epidemiological indicators in a positive direction, while also increasing the focus on the problem and reinforcing health awareness. From the perspective of management steps to be taken, the results of the research suggest that communication of such campaigns can be managed using the AIDA model.
By defining its aspects as a sub-activity of the controlling management function (Vitezić and Vitezić, 2015), it is possible to set up the requirements that managers expect as a result of a campaign communication. The model can also be used to measure the success of these results, aiding the process of consumer opinion polling. Feedback from the results can serve as a valuable input to the planning function (Boulton et al., 1982) of management. In particular, management of the campaign can use the input received from the survey to label an effective Dry November communication. Based on this, management can incorporate feedback for future plans (e.g. targeting those who have the greatest impact on potential addicts: GPs and friends) and in the field of controlling, precisely define what changes and when they expect as a result of the programme to take place.

\section{Further research suggestions}

As further research, it would be advisable to analyse other addiction prevention campaigns based on the AIDA model. Interestingly, in contrast to the viewpoint of service providers, who suggested that famous people might have major influence on consumer opinion, the results of the questionnaire showed that celebrities and social trends have an insignificant influence on consumer decisions in this area. A comprehensive study verifying this result for various societal groups and generations on different forms of addictions may be representative about this assumption. As today's trends dictate, companies consider aligning their goals with social interests important (Vágási, 2004). From this perspective, it may be worthwhile to investigate how prevention of addictions or the promotion of moderate consumption occurs in corporate social responsibility activities of companies.

In terms of the applicability of the gap model (Zeithaml et al., 1990), it is worthwhile to examine a specific programme, campaign or service aimed at addiction, which is designed in relation to personal needs or the specifics of a well-defined target group. In this case, from a managerial perspective, KPIs (Star et al., 2016) could be used to measure the differences between expected and actual results for each gap, which could help in the future development of these services. At the same time, it would allow continuous measurement and comparison of the results according to the planning phase of service components. 


\section{Acknowledgements}

\section{This research was supported by the ÚNKP- 크 18-3-II. New National Excellence Programme

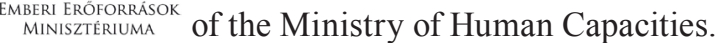

\section{References}

Ádány, R. (2012) "3. fejezet I. A megelőző orvostan és népegészségtan tárgya" (Subject of preventive medicine and public health), In: Árány, R. (ed.), Megelőző orvostan és népegészségtan, Medicina Kiadó, Budapest, Hungary, pp. 7-26. (in Hungarian)

Alford, J., Yates, S. (2014) "Mapping public value processes", International Journal of Public Sector Management, 27(4), pp. 334-352.

https://doi.org/10.1108/IJPSM-04-2013-0054

Aras, M., Jasruddin, J., Akib, H., Syam, H. (2018) "Marketing Mix Study at Hero Tailor", IOSR Journal of Business and Management (IOSR-JBM), 20(4), pp. 45-51. https://doi.org/10.9790/487X-2004084551

Bíró, É., Dezső, D., Sándor J., Ádány, R. (2018) "Inequalities in Hungarian adolescents' health, health behaviour and well-being, based upon the results of a cross-sectional survey at settlement level, using the Health Behaviour in School-aged Children questionnaire", Children and Youth Services Review, 90, pp. 15-20. https://doi.org/10.1016/j.childyouth.2018.05.008

Bitar, A. R. (2018) "Diet and the Disease of Civilization", Rutgers University Press, London, UK.

Bodrogi, A. (2011) "Az Alkoholizmus Kognitív Viselkedésterápiás Megközelítése" (Cognitive behavioural therapy of alcoholism), Magyar Pszichológiai Szemle, 66(1), pp. 141-156. (in Hungarian) https://doi.org/10.1556/mpszle.66.2011.1.9

Bóta, L. (2009) "Web page navigation analyses for marketing management decision-making", Periodica Polytechnica Social and Management Sciences, 17(2), pp. 89-95. https://doi.org/10.3311/pp.so.2009-2.05

Boulton, W. R., Lindsay, W. M., Franklin, S. G., Rue, L. W. (1982) "Strategic Planning: Determining the Impact of Environmental Characteristics and Uncertainty", Academy of Management Journal, 25(3), pp. 500-509. https://doi.org/10.5465/256076

Caplan, G. (1964) "Principles of preventive psychiatry", Basic Books, New York, NY, USA

Dávid, F. (2019) "Interview with the main organiser of the Dry November campaign", Interviewed by Tímea Dóra, [personal format] Budapest, Hungary, 26 February 2019.

Dry November Facebook Group [online] Available at: https://www. facebook.com/groups/1780393285542234/?ref=share [Accessed: 13 February 2021]

Eiglier, P., Langeard, E. (1976) "Principes de politique pour les enterprises de services" (Principles of marketing policy for service companies), L'Institut d'Administration des Enterprises, Université d'Aix-Marseille, Marseille, France. (in French)

European Monitoring Centre for Drugs and Drug Addiction (EMCDDA) "Hungary Drug Report 2018", [pdf] EMCDDA, Lisbon, Portugal, Available at: http://www.emcdda.europa.eu/system/files/publications/11299/hungary-cdr-2018-with-numbers.pdf [Accessed: 20 April 2019]
Goldman, D., Oroszi, G., Ducci, F. (2005) "The genetics of addictions: uncovering the genes", Nature Reviews Genetics, 6(7), pp. 21-532. https://doi.org/10.1038/nrg1635

Grönroos, C. (2007) "An Applied Service Marketing Theory", European Journal of Marketing, 16(7), pp. 30-41. https://doi.org/10.1108/EUM0000000004859

Hadiyati, E. (2016) "Study of Marketing Mix and Aida Model to Purchasing on Line Product in Indonesia", British Journal of Marketing Studies, 4(7), pp. 49-62. [online] Available at: http:// www.eajournals.org/wp-content/uploads/Study-of-MarketingMix-and-Aida-Model-to-Purchasing-On-Line-Product-inIndonesia.pdf [Accessed: 12 January 2020]

Hahn, R. A., Truman, B. I. (2015) "Education Improves Public Health and Promotes Health Equity", International Journal of Health Services, 45(4), pp. 657-678. https://doi.org/10.1177/0020731415585986

Howard, J., Taylor, J. A., Ganikos, M. L., Holder, H. D., Godwin, D. F., Taylor, E. D. (1988) "An overview of prevention research: issues, answers, and new agendas", Public Health Reports, 103(6), pp. 674-683. [online] Available at: https://www.ncbi.nlm.nih.gov/ pmc/articles/PMC1478140/ [Accessed: 12 January 2020]

Hungarian Central Statistical Office (HCSO) (2015) "Európai lakossági egészségfelmérés, 2014" (European Health Interview Survey, 2014), Statisztikai Tükör, 29, pp. 1-8. [online] Available at: https://www. ksh.hu/docs/hun/xftp/stattukor/elef14.pdf [Accessed: 20 April 2019] (in Hungarian)

Hungarian Central Statistical Office (HCSO) (2017) "Halálozások a leggyakoribb halálokok szerint (1990-)" (Deaths sorted by frequent death causes (1990-)), [online] Available at: http://www.ksh.hu/docs/ hun/xstadat/xstadat_eves/i_wnh001.html [Accessed: 28 June 2019], (in Hungarian)

Jaakkola, E., Helkkula, A., Aarikka-Stenroos, L. (2015) "Service experience co-creation: Conceptualization, implications, and future research directions", Journal of Service Management, 26(2), pp. 182-205.

https://doi.org/10.1108/JOSM-12-2014-0323

Joseph, W. B. (1996) "Internal Marketing Builds Service Quality", Journal of Health Care Marketing, 16(1), pp. 54-59. [online] Available at: http://home.bi.no/fg196053/orgcom/internmkt.pdf [Accessed: 10 January 2020]

Kelley, E., Moy, E., Kosiak, B., McNeill, D., Zhan, C., Stryer, D., Clancy, C. (2004) "Prevention Health Care Quality in America: Findings from the First National Healthcare Quality and Disparities Reports", Preventing Chronic Disease, 1(3), Article number: A03. [online] Available at: https://www.ncbi.nlm.nih.gov/pmc/articles/ PMC1253468/ [Accessed: 10 January 2020]

Kenesei, Zs., Kolos, K. (2014) "Szolgáltatásmarketing és Menedzsment" (Service Marketing and Management), Alinea Kiadó, Budapest, Hungary. (in Hungarian) 
Kotler, P., Hayes, T., Bloom, P. N. (2002) "Marketing Professional Services", Prentice Hall Press, Englewood Cliffs, NJ, USA.

Kotler, P., Keller, K. L. (2012) "Designing and Managing Integrated Marketing Communications", In: Marketing Management, Prentice Hall, Upper Saddle River, NJ, USA, pp. 75-501.

Mackenbach, J. P., Kulhánová, I., Bopp, M., Borrell, C., Deboosere, P., Kovács, K., ... de Gelder, R. (2015) "Inequalities in AlcoholRelated Mortality in 17 European Countries: A Retrospective Analysis of Mortality Registers", PLOS Medicine, 12(12), Article number: e1001909.

https://doi.org/10.1371/journal.pmed.1001909

Malhotra, N. K. (2009) "Review of Marketing Research", Review of Marketing Research, Emerald Group Publishing Limited, Bingley, UK. https://doi.org/10.1108/S1548-6435(2008)0000005004

Marián, A., Balázs, B., Bujdosó, B., Lencse, M., Rácz, J. (2004) "Terápiás és alacsony küszöbü programok kvalitatív értékelése a kliensek szemszögéből. Összefoglalő a Kék Pont Drogkonzultációs Központ klienseinek utánkövetéses vizsgálatáról" (Qualitative evaluation of therapeutic and low threshold programs from the perspective of clients. Summary of the follow-up of Blue Point Drug Counseling Center clients), ADDIKTOLÓGIA, 3(2), pp. 160-190. [online] Available at: https://bit.ly/2wbWj10 [Accessed: 12 January 2020] (in Hungarian)

Michaelson, D., Stacks, D. W. (2011) "Standardization in Public Relations Measurement and Evaluation", Public Relations Journal, 5(2), pp. 1-22. [online] Available at: https://instituteforpr.org/ wp-content/uploads/DonStacks-and-David-Michaelson.pdf [Accessed: 12 January 2020]

Organisation for Economic Co-operation and Development (OECD) "OECD Data: Daily smokers", [online] Available at: https://data. oecd.org/healthrisk/daily-smokers.htm [Accessed: 20 April 2019]

Paksi, B., Demetrovics, Zs., Magi, A., Felvinczi, K. (2018) "A magyarországi felnőtt népesség droghasználata - az országos lakossági adatfelvétel az addiktológiai problémákról 2015 (OLAAP 2015) reprezentatív lakossági felmérés alapján" (Drug use among the Hungarian adult population - National population survey on addiction problems 2015 (OLAAP 2015) based on a representative population survey), Magyar Pszichológiai Szemle, 73(4/2), pp. 541-565. (in Hungarian) https://doi.org/10.1556/0016.2018.73.4.2

Parasuraman, A., Zeithaml, V. A., Berry, L. L. (1985) "A Conceptual Model of Service Quality and Its Implications for Future Research", Journal of Marketing, 49(4), pp. 41-50.

https://doi.org/10.2307/1251430

Price, A. W., Emshoff, J. G. (1997) "Breaking the cycle of addiction: prevention and intervention with children of alcoholics", Alcohol Health and Research World, 21(3), pp. 241-246. [online] Available at: https://www.ncbi.nlm.nih.gov/pubmed/15706776 [Accessed: 12 January 2020]

Ramachandran, A., Chidambaram, V. (2012) "A review of customer satisfaction towards service quality of banking sector", Periodica Polytechnica Social and Management Sciences, 20(2), pp. 71-79. https://doi.org/10.3311/pp.so.2012-2.02
Regidor, E., de la Fuente, L., Gutiérrez-Fisac, J. L., de Mateo, S., Pascual, C., Sánchez-Payá, J., Ronda, E. (2007) "The Role of the Public Health Official in Communicating Public Health Information", American Journal of Public Health, 97(1), pp. 93-97. https://doi.org/10.2105/AJPH.2006.094623

Rehman, F. U., Nawaz, T., Ilyas, M., Hyder, S. (2014) "A Comparative Analysis of Mobile and Email Marketing Using AIDA Model", Journal of Basic and Applied Scientific Research, 4(6), pp. 38-49. [online] Available at: https://www.textroad.com/pdf/JBASR/J.\%20 Basic.\%20Appl.\%20Sci.\%20Res.,\%204(6)38-49,\%202014.pdf [Accessed: 12 January 2020]

Sasser, W. E. (1976) "Match Supply and Demand in Service Industries", Harvard Business Review, 54(6), pp. 133-140. [online] Available at: https://hbr.org/1976/11/match-supply-and-demand-in-serviceindustries [Accessed: 02 January 2020]

Simeonsson, R. J. (1991) "Primary, Secondary, and Tertiary Prevention in Early Intervention", Journal of Early Intervention, 15(2), pp. 124-134. https://doi.org/10.1177/105381519101500202

Simon, J. (2010) "Marketing az egészségügyben" (Marketing in health care), Akadémia Kiadó, Budapest, Hungary. (in Hungarian) https://doi.org/10.1556/9789630597807

Star, S., Russ-Eft, D., Braverman, M. T., Levine, R. (2016) "Performance Measurement and Performance Indicators: A Literature Review and a Proposed Model for Practical Adoption", Human Resource Development Review, 15(2), pp. 151-181. https:/doi.org/10.1177/1534484316636220

Stokes, D., Bergin, R. (2006) "Methodology or "methodolatry"? An evaluation of focus groups and depth interviews", Qualitative Market Research, 9(1), pp. 26-37. https://doi.org/10.1108/13522750610640530

Süle, M. (2012) "Advertising effects vs. consumer consciousness Results of an empirical study", Periodica Polytechnica Social and Management Sciences, 20(2), pp. 91-103. https://doi.org/10.3311/pp.so.2012-2.04

Tokarčiková, E. (2011) "Influence of social networking for enterprise's activities", Periodica Polytechnica Social and Management Sciences, 19(1), pp. 37-41. https://doi.org/10.3311/pp.so.2011-1.05

Vágási, M. (2004) "Integration of the Sustainability Concept Into Strategy and Marketing", Periodica Polytechnica Social and Management Sciences, 12(2), pp. 245-260. [online] Available at: https://pp.bme. hu/so/article/view/1672 [Accessed: 10 January 2020]

Veres, Z. (2005) "Szolgáltatásmarketing" (Service marketing), KJKKRSZÖV Jogi és Üzleti Kiadó Kft., Budapest, Hungary. (in Hungarian)

Vermeir, P., Vandijck, D., Degroote, S., Peleman, R., Verhaeghe, R., Mortier, E., ... Vogelaers, D. (2015) "Communication in healthcare: A narrative review of the literature and practical recommendations", International Journal of Clinical Practice, 69(11), pp. 1257-1267.

https://doi.org/10.1111/ijcp.12686 
Vitezić, N., Vitezić, V. (2015) "A cConceptual Model of Linkage Between Innovation Management and Controlling in the Sustainable Environment", Journal of Applied Business Research (JABR), 31(1), pp. 175-184.

https://doi.org/10.19030/jabr.v31i1.8999

World Health Organization (WHO) "Status Report on Alcohol and Health in 35 European Countries 2013", [pdf] WHO Regional Office of Europe, Copenhagen, Denmark, Available at: http:// www.euro.who.int/_data/assets/pdf_file/0017/190430/StatusReport-on-Alcohol-and-Health-in-35-European-Countries.pdf [Accessed: 20 April 2019]
Zainuddin, N., Previte, J., Russell-Bennett, R. (2011) "A social marketing approach to value creation in a well-women's health service", Journal of Marketing Management, 27(3-4), pp. 361-385. https://doi.org/10.1080/0267257X.2011.547081

Zeithaml, V. A., Parasuraman, A. P., Berry, L. L. (1990) "Delivering Quality Service: Balancing Customer Perceptions and Expectations", The Free Press, New York, NY, USA.

Zeithaml, V. A., Bitner, M. J., Gremler, D. D. (2006) "Services Marketing: Integrating Customer Focus across the Firm", McGraw- Hill, New York, NY, USA. 